\title{
Study on Pilot-scale Experiment of Electro-catalytic Oxidation in the Deep Treatment of Coking Wastewater
}

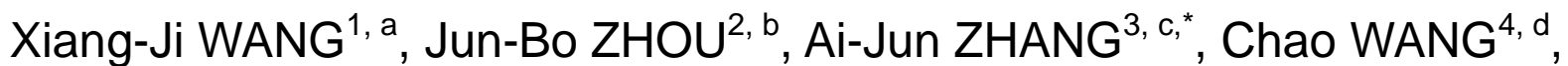 \\ Dong $\mathrm{XIAO}^{5, \mathrm{e}}$, Zhi-Na $\mathrm{JIN}^{6, \mathrm{f}}$, Yuan MIAO ${ }^{7, g}$ and Tong-Tong $\mathrm{ZHI}{ }^{8, \mathrm{~h}}$
}

1,2,3,4 College of Mechanical and Electrical Engineering, Beijing University of Chemical Technology, Beijing, 100029, China

\author{
5,6,7,8 Jingrun Envirotech Co., Ltd. Beijing, 100085, China \\ a1023645453@qq.com, bzhogab@163.com, ${ }^{c}$ e.zaj@163.com, d1183434284@qq.com, \\ edonna@jingrun-bj.com, jinzhina@jingrun-bj.com, ${ }^{9}$ miaoyuan@jingrun-bj.com, \\ hzhitongtong@jingrun-bj.com
}

Keywords: Electro-catalytic oxidation, Coking wastewater, COD, Operating cost, Deep treatment.

\begin{abstract}
To investigate the reduction of the COD of coking wastewater by electro-catalytic oxidation, the electro-catalytic oxidation pilot-scale experiment was carried out using the coking wastewater treated by $\mathrm{A}^{2} / \mathrm{O}$ and the coking wastewater treated by $\mathrm{A}^{2} / \mathrm{O}$ and fenton oxidation. And the modified electrode material $\left(\mathrm{Ti} / \mathrm{PbO}_{2}\right)$ plate was used as anode and $316 \mathrm{~L}$ stainless steel plate was used as cathode. The effect of electro-catalytic oxidation on the COD removal rate of the two coking wastewater was studied. The experimental results showed that the COD of the coking wastewater treated by $\mathrm{A}^{2} / \mathrm{O}$ was reduced from $300 \mathrm{mg} / \mathrm{L}$ to $165 \mathrm{mg} / \mathrm{L}$ and the removal rate reached $45 \%$ in the electro-catalytic oxidation unit, and the operating cost was less than $3 \mathrm{yuan} / \mathrm{m}^{3}$. In addition, the COD of the coking wastewater treated by $\mathrm{A}^{2} / \mathrm{O}$ and fenton was reduced from $130 \mathrm{mg} / \mathrm{L}$ to $30 \mathrm{mg} / \mathrm{L}$ and the removal rate reached $76.5 \%$ in the electro-catalytic oxidation unit oxidation, and the operating cost was less than 6.2 yuan $/ \mathrm{m}^{3}$. Furthermore, the COD of the wastewater treated by fenton oxidation and electro-catalytic oxidation was less than $40 \mathrm{mg} / \mathrm{L}$, which suggested that the electro-catalytic oxidation was a reliable, steady and economical method for the deep treatment of coking wastewater.
\end{abstract}

\section{Introduction}

Coking wastewater is a kind of toxic, harmful high-concentration organic wastewater produced by high-temperature dry distillation, gas purification and chemical product recovery and refining processes but it is difficult to degrade [1]. It mainly contains phenolic compounds, aliphatic compounds, heterocyclic compounds, polycyclic aromatic hydrocarbons, ammonia nitrogen, sulfides, cyanide, etc. The technology used in most coking plants for the wastewater treatment is traditional biochemical treatment technology which consists of mud sedimentation tank, degreasing tank, heating pool and other equipment. In the deep treatment of coking wastewater, the traditional methods mainly includeal adding chemicals, fenton oxidation, activated carbon adsorption, ozonation. Though the organic pollutants in the wastewater can be removed, the COD cannot meet the exclusion criteria and still cause great harm to the environment[2,3,4], and it has high operating costs, secondary pollution and other issues.

The electro-catalytic oxidation technology produces strong oxidants such as hydroxyl radicals $(\cdot \mathrm{OH})$ and hydrogen peroxide $\left(\mathrm{H}_{2} \mathrm{O}_{2}\right)$ on the surface of the coated electrode through electrode reaction, which can oxidize and degrade organic pollutants. The electro-catalytic oxidation technology requires a small footprint, mild operating conditions without introduction of chemicals, which is not easy to produce toxic intermediates without secondary pollution, and also has the advantages of air flotation and bactericidal action. Compared with developed countries such as Britain and the United States, China's electro-catalytic oxidation technology is mainly concentrated in the treatment of heavy metal wastewater. In terms of organic wastewater treatment, China is still 
in the development stage [5].

Since the titanium-based metal oxide electrode was first prepared, it has evolved from a single species to dope with different metal coatings or with intermediate coatings. Generally, there are a Ru-based coating electrode, an Ir-based coating electrode, a $\mathrm{PbO}_{2}$ coating electrode etc that have been applied in the field of water treatment $[6,7,8]$. At present, the deep treatment of coking wastewater with titanium-based metal oxide electrodes has been extensively studied.

For the deep treatment of coking wastewater, most of the research focused on the reduction of COD, but did not study the energy consumption of the experiment. X. He et al. [9] used $\mathrm{Ti} / \mathrm{RuO}_{2}-\mathrm{IrO}_{2}$ as anode and platinum wire as cathode studied the feasibility of deep treatment of coking wastewater. The effect of current density and electrode spacing on the treatment effect was discussed. Experiments showed that the $\mathrm{COD}$ and $\mathrm{NH}_{3}-\mathrm{N}$ are reduced by $62 \%$ and $96 \%$, respectively, after electro-catalytic oxidation. In addition, GC-MS analysis showed that some refractory and toxic compounds in the wastewater were completely eliminated, such as phenanthrene, quinoline and pyrimidine. The study has strong reference value, but no research on energy consumption. Q. Gu et al. [10] used $\mathrm{Ti} / \mathrm{Ru}_{0.3} \mathrm{Ti}_{0.7} \mathrm{O}_{2}$ as anode and $\mathrm{Ti}$ as cathode to study the effects of electro-catalytic oxidation parameters on coking wastewater treatment. The results showed that under the irradiation of ultraviolet light at $254 \mathrm{~nm}$, the COD of coking wastewater treated can be reduced by $69 \%$ and the TN can be reduced by $61 \%$. Compared with non-ultraviolet radiation, there is a significant improvement. But the experiment did not study the energy consumption.

At home and abroad, there are many studies on the treatment of wastewater by electro-catalytic oxidation. However, most of them focus on the study of electrode material, current density, plate spacing, cell voltage, etc. [11], but there is little research on energy consumption. Although electro-catalytic oxidation can effectively treat coking wastewater and improve the biodegradability of the wastewater, high energy consumption restricts its application in wastewater treatment [12].

In this paper, as for the coking wastewater treated by $\mathrm{A}^{2} / \mathrm{O}$ and the coking wastewater treated by $\mathrm{A}^{2} / \mathrm{O}$ and fenton oxidation, the effect of electro-catalytic oxidation on COD removal rate and energy consumption of the two kinds of the coking wastewater was investigated to reduce the COD of coking wastewater. The paper provides a reliable, steady and economical treatment method for the deep treatment of coking wastewater.

\section{Experimental}

\section{Source and Quality of the Experimental Water}

The coking wastewater in the experiment was obtained from the wastewater processing station of a coking company in Shanxi Province. The plant produces 600,000 tons of coke per year. At present, the existing coking wastewater treatment process of the plant is oil separation, anaerobic, anoxic, aerobic, fenton catalytic oxidation, sedimentation. Because this coking wastewater has the characteristics of poor biodegradability, high organic matter concentration, complex composition and toxicity, after conventional biochemical treatment and deep treatment with fenton oxidation, the COD of biochemical treatment is about $300 \mathrm{mg} / \mathrm{L}$, and the COD of fenton deep treatment is about $130 \mathrm{mg} / \mathrm{L}$, which cannot meet the discharge requirements of the plant: COD less than $40 \mathrm{mg} / \mathrm{L}$. Therefore, the water inflow in this electro-catalytic experiment is divided into two types: One is the inflow from the secondary settling tank with the COD of about $300 \mathrm{mg} / \mathrm{L}$, and the other is the inflow from the fenton oxidation tank with the COD of about $130 \mathrm{mg} / \mathrm{L}$. 


\section{Experimental Process}

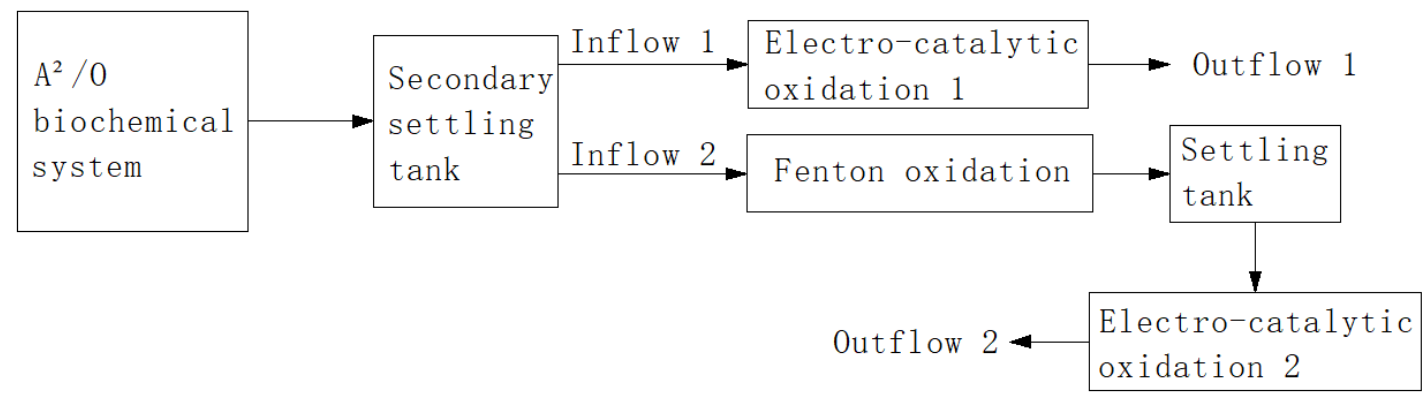

Fig. 1 Flow scheme of the deep treatment of coking wastewater

The experimental process was shown in Figure 1. The water inflow in this electro-catalytic experiment was divided into two types: the coking wastewater treated by $\mathrm{A}^{2} / \mathrm{O}$, and the coking wastewater treated by $\mathrm{A}^{2} / \mathrm{O}$ and fenton oxidation. The water produced by the second settling tank had a high COD and contains a large amount of suspended matter impurities. The COD and suspended matter of the water produced second settling tank after deep treatment of fenton oxidation were much reduced. Where the removal efficiency of COD was more than 55\% and reduced the concentration of suspended solids and $\mathrm{HCO}_{3}{ }^{-}$in the coking wastewater. The water in the settling tank was sucked into the electro-catalytic oxidation reactor through the submersible pump.

\section{Instrument and Materials}

The fenton oxidation unit used the existing equipment of the factory. A schematic diagram of the electro-catalytic experimental apparatus was shown in Figure 2.

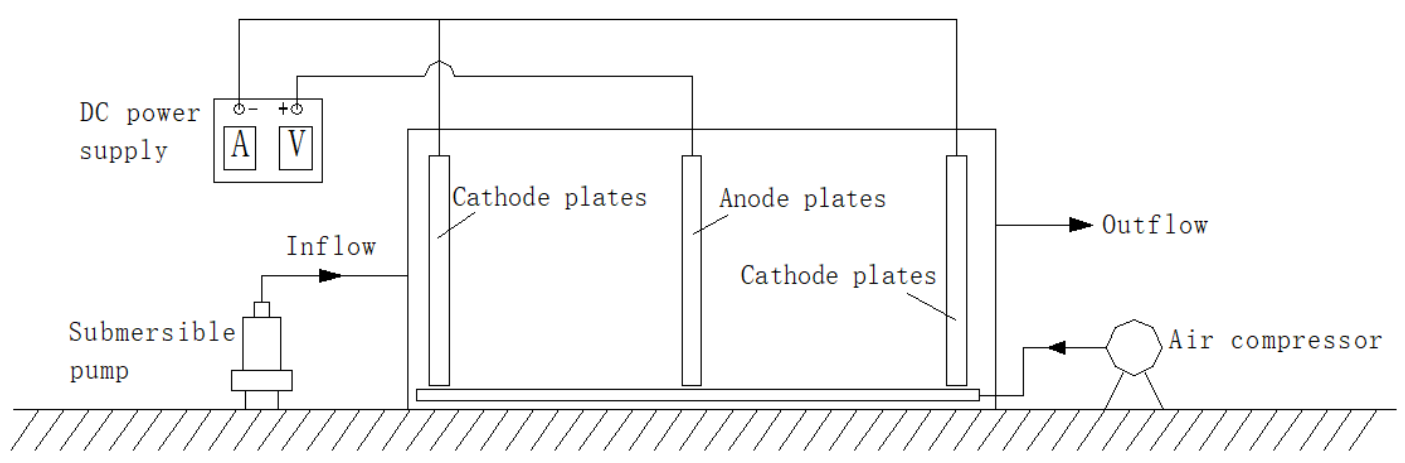

Fig. 2 Schematic diagram of the experimental electro-catalytic apparatus

Electro-catalytic oxidation equipment mainly includes: electro-catalytic oxidation reactor, anode plate, cathode plate, variable frequency low-pressure high-current DC power supply, air compressor, submersible pump.

Electro-catalytic oxidation reactor tank designed from Jingrun Envirotech Co., Ltd. The electro-catalytic oxidation reactor is semi-folding rectangular structure with a size of $700 \mathrm{~mm} \times$ $1960 \mathrm{~mm} \times 740 \mathrm{~mm}$, and mainly includes an influent regulating tank, a diversion tank, a collecting tank, a water generating tank and a drain tank. The anode plates with a size of $500 \mathrm{~mm} \times 3 \mathrm{~mm} \times$ $500 \mathrm{~mm}$ and the cathode plates with a size of $500 \mathrm{~mm} \times 2 \mathrm{~mm} \times 500 \mathrm{~mm}$ designed from Jingrun Envirotech Co., Ltd. Variable frequency low-pressure high-current DC power supply (GGF3000A12V) was designed from Jingrun Envirotech Co., Ltd. Air compressor (W-1.05) purchased from Weifang Licai Machinery Co., Ltd. The submersible pump (QDX3-24-0.75T2) purchased from Shanghai Xinxishan Industrial Co., Ltd. 


\section{Results and Discussion}

\section{Efficiency of Electro-Catalytic Oxidation}

After two months of steady operation, the COD of the coking wastewater was tested. The COD of the electro-catalytic oxidation 1 and the electro-catalytic oxidation 2 in Figure 1 was shown in Table 1 .

Table 1 COD in each process section

\begin{tabular}{cccc}
\hline $\begin{array}{c}\text { Processing } \\
\text { method }\end{array}$ & Inflow COD (mg/L) & $\begin{array}{c}\text { Outflow COD } \\
(\mathrm{mg} / \mathrm{L})\end{array}$ & Removal rate \\
\hline $\begin{array}{c}\text { Electro-catalytic } \\
\text { oxidation 1 }\end{array}$ & 300 & 165 & $45 \%$ \\
$\begin{array}{c}\text { Electro-catalytic } \\
\text { oxidation 2 }\end{array}$ & 130 & 30 & $76.9 \%$ \\
\hline
\end{tabular}

The result showed that for the coking wastewater of the secondary settling tank, electro-catalytic oxidation could remove a part of the COD, the removal rate reached only $45 \%$ and it was far from meeting the requirement of less than $40 \mathrm{mg} / \mathrm{L}$. Then, after the electro-catalytic oxidation of the fenton oxidized wastewater, which met emission requirements with COD less than $40 \mathrm{mg} / \mathrm{L}$, the removal rate reached $76.9 \%$. The first reason is that the secondary settling tank produced a large amount of suspended solids, lots of hydroxyl radicals $(\cdot \mathrm{OH})$ from electro-catalytic oxidation reactor be absorbed and the fouling of the cathode plate caused electro-catalytic oxidation efficiency decreases in the electro-catalytic reactor. The second reason is that a large amount of $\mathrm{HCO}_{3}{ }^{-}$in the coking wastewater, which also can react with $\cdot \mathrm{OH}$, while $\mathrm{H}_{2} \mathrm{SO}_{4}$ added in fenton oxidation can effectively remove the concentration of the $\mathrm{HCO}_{3}^{-}$in the wastewater. Therefore, the electro-catalytic efficiency has been improved after the coking wastewater is treated by fenton oxidation.

\section{Stability of Operation of Electro-Catalytic Oxidation}

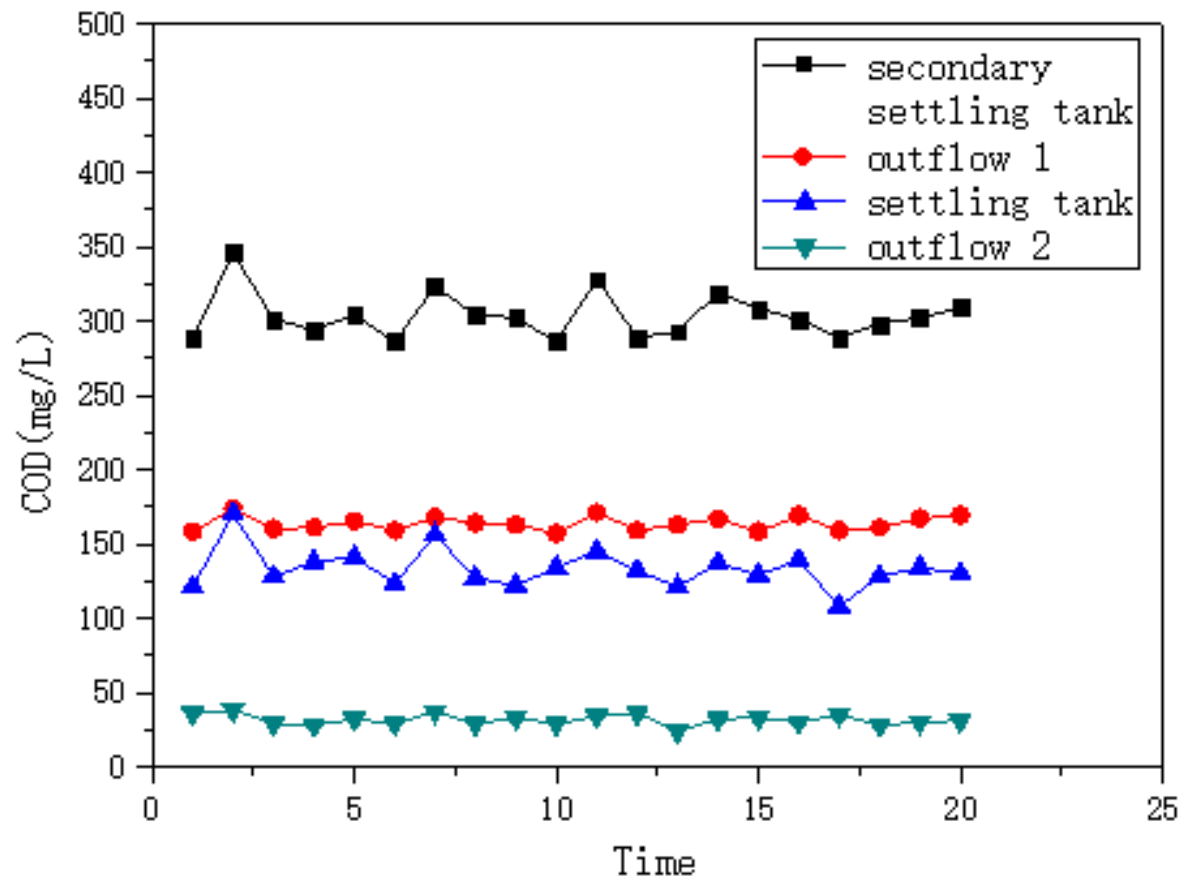

Fig. 3 Removal effect of COD in each process section

The COD of the wastewater in each process section was shown in Figure 3. Through 20 
consecutive sampling tests with an interval of 15 min each sample test, it was found that the COD fluctuation of the outflow 1 was $60 \mathrm{mg} / \mathrm{L}$ when the COD of inflow 1 changed from $157 \mathrm{mg} / \mathrm{L}$ to 174 $\mathrm{mg} / \mathrm{L}$. The COD fluctuation of the outflow 2 was $62 \mathrm{mg} / \mathrm{L}$ when the COD of inflow 2 changed from $24 \mathrm{mg} / \mathrm{L}$ to $38 \mathrm{mg} / \mathrm{L}$. Therefore, the COD of the two outflows were relatively steady when the COD of their inflow changed.

Figure 3 showed that the COD of outflow 1 was far higher the emission requirements with the low removal efficiency. However, outflow 2 could meet emission requirements. Because the coking wastewater treated by the $\mathrm{A}^{2} / \mathrm{O}$ process has a poor sedimentation effect in the secondary settling tank, and the concentration of the suspended solid and $\mathrm{HCO}_{3}{ }^{-}$was high and the electrode plates are serious foul reducing the efficiency of electro-catalytic oxidation. When the COD of the fenton oxidation outflow was $108 \mathrm{mg} / \mathrm{L}$ to $170 \mathrm{mg} / \mathrm{L}$, the COD of the outflow 2 of electro-catalytic oxidation was still steady below $40 \mathrm{mg} / \mathrm{L}$.

\section{Operating Costs}

According to the experimental situation, except the operating cost of the $\mathrm{A}^{2} / \mathrm{O}$ process, the operating cost of outflow 1 was mainly the energy consumption of electro-catalytic oxidation and the operating cost of outflow 2 mainly includes the cost of fenton oxidation and the electricity consumption of electro-catalytic oxidation. The specific operating costs except the operating cost of the $\mathrm{A}^{2} / \mathrm{O}$ process were shown in Table 2 and Table 3.

Table 2 Operating costs of outflow 1

\begin{tabular}{cccc}
\hline Types & Consumption & Unit price & $\begin{array}{c}\text { Total price } \\
\left.\text { (yuan } / \mathrm{m}^{3} \text { water }\right)\end{array}$ \\
\hline $\begin{array}{c}\text { Energy } \\
\text { consumption }\end{array}$ & $6 \mathrm{kwh} / \mathrm{m}^{3}$ water & $0.5 y u a n / \mathrm{kwh}$ & 3.000 \\
\hline
\end{tabular}

Table 3 Operating costs of outflow 2

\begin{tabular}{cccc}
\hline Types & Consumption & Unit price & $\begin{array}{c}\text { Total price } \\
\text { (yuan } / \mathrm{m}^{3} \text { water) }\end{array}$ \\
\hline $\mathrm{FeSO}_{4} \bullet 7 \mathrm{H}_{2} \mathrm{O}$ & $0.75 \mathrm{~kg} / \mathrm{m}^{3}$ water & $0.300 \mathrm{yuan} / \mathrm{kg}$ & 0.225 \\
$27.5 \% \mathrm{H}_{2} \mathrm{O}_{2}$ & $0.73 \mathrm{~kg} / \mathrm{m}^{3}$ water & $1.200 \mathrm{yuan} / \mathrm{kg}$ & 0.876 \\
$98 \% \mathrm{H}_{2} \mathrm{SO}_{4}$ & $0.5 \mathrm{~kg} / \mathrm{m}^{3}$ water & $0.600 \mathrm{yuan} / \mathrm{kg}$ & 0.6 \\
$\mathrm{PAM}$ & $0.005 \mathrm{~kg} / \mathrm{m}^{3}$ water & $20 \mathrm{yuan} / \mathrm{kg}$ & 0.100 \\
$30 \% \mathrm{NaOH}$ & $1.1 \mathrm{~kg} / \mathrm{m}^{3}$ water & $1.200 \mathrm{yuan} / \mathrm{kg}$ & 1.32 \\
Energy & $6 \mathrm{kwh} / \mathrm{m}^{3}$ water & 0.5 yuan $/ \mathrm{kwh}$ & 3.000 \\
consumption & ---- & --- & 6.121 \\
Total cost & & &
\end{tabular}

Comparing the operating costs of the above two outflow, although the operating cost of outflow 1 is low, it does not meet the water production requirements, however, it also provides a reference for the deep treatment of coking wastewater treated by $\mathrm{A}^{2} / \mathrm{O}$ by electro-catalytic oxidation. The operating cost of outflow 2 was less than $6.2 \mathrm{yuan} / \mathrm{m}^{3}$, and it can meet the water production requirements of manufacturer. Therefore, the electro-catalytic oxidation was an economical method for the deep treatment of the coking wastewater treated by $\mathrm{A}^{2} / \mathrm{O}$ and fenton oxidation.

\section{Conclusions}

For the coking wastewater treated by $\mathrm{A}^{2} / \mathrm{O}$, the removal efficiencies of COD by electro-catalytic oxidation was $46.8 \%$ while the removal efficiencies of COD by electro-catalytic oxidation was76.9\% for the coking wastewater treated by $\mathrm{A}^{2} / \mathrm{O}$ and fenton oxidation, which suggested that the removal efficiencies of COD by electro-catalytic oxidation was much influenced by its infow 
quality and the front processing of the wastewater.

This experiment proved the feasibility of electro-catalytic oxidation for the deep treatment of the coking wastewater by $\mathrm{A}^{2} / \mathrm{O}$ and fenton oxidation. The COD of the coking wastewater treated by $\mathrm{A}^{2} / \mathrm{O}$ and fenton was reduced from $130 \mathrm{mg} / \mathrm{L}$ to $30 \mathrm{mg} / \mathrm{L}$ and the removal rate reached $76.5 \%$ in the electro-catalytic oxidation unit oxidation, and the operating cost was less than $6.2 \mathrm{yuan} / \mathrm{m}^{3}$.

\section{Acknowledgement}

This research was supported by Beijing University of Chemical Technology and Jingrun Envirotech Co., Ltd.

\section{Reference}

[1] Zhang H, Dong C, Bian L, et al. Experiment Study on Corrosion Control Using Coking Wastewater as Circulating Cooling Water[J]. Earth Science Frontiers, 2008, 15(4):186-189.

[2] Xiao B Y, Shi J, Li Y, et al. Analysis of coking wastewater treatment status and technology development trend[C]. Baosteel Academic Annual Meeting, 2013.

[3] Li J, She X. Analysis of coking wastewater treatment status and technology development trend[J]. Urban Construction Theory Research, 2014(11).

[4] Liu R. Progress in application and research of coking wastewater treatment technology [J]. Urban Construction Theory Research: Electronic Edition, 2014(21).

[5] Huang H, Ai F H, Ma C A, et al. Catalytic oxidation treatment of refractory organic wastewater[J]. Chemical Research and Application, 2013, (2):157-160.

[6] Wang C R, Qi J, Zhang M R, et al. Electrochemical oxidation and denitrification BAF combined with deep treatment of coking wastewater [J]. Industrial Water Treatment, 2016, 36(11):74-77.

[7] Zhou J, Wei J, Zhang Q L. Preparation of Metal Oxide Electrode and Its Electrochemical Properties [J]. Water Treatment Technology, 2013, 39(12):28-32.

[8] Wang C, Zhang M, Liu W, et al. Effluent characteristics of deep treatment for biotreated coking wastewater by electro-chemical technology using BDD anodes[J]. Environmental Science and Pollution Research, 2015, 22(9):6827- 6834.

[9] X. He, Chai Z, Li F, et al. deep treatment of biologically pretreat-ed coking wastewater by electrochemical oxidation using Ti/RuO2-IrO2, electrodes[J]. Journal of Chemical Technology \&Biotechnology, 2013, 88(8):1568-1575.

[10]Q. Gu, Zheng J. Study on the Electrochemical Oxidation Treatment of Coking Wastewater by DSA Anode[C]// Asia-Pacific Energy Equipment Engineering Research Conference. 2015.

[11] Yue Lin, Wang Qishan, Guo Jianbo, et al. Removal of ammonia nitrogen from landfill leachate by electro-catalytic oxidation [J]. Industrial Water Treatment, 2010, 30(10):52-55.

[12]Jing Xiaohui, Cao Hui, Ding Xinyu, ea al. Experimental study on the treatment of printing and dyeing wastewater by three-dimensional three-phase electrode[J]. Knitting Industry, 2010(12):44-47. 